\title{
Characterisation of Phytolith Production and Their Taxonomic Use among Five Species of Aristida
}

\author{
PI. Jattisha ${ }^{1}$, M. Sabu ${ }^{2}$ \\ ${ }^{1,2}$ Department of Botany, University of Calicut, Kerala, India
}

\begin{abstract}
Phytoliths are amorphous silicon dioxide depositions in and around the cells of certain plants. Phytoliths of Poaceae are of great importance in the field of taxonomy and Archeology. Present study confirms the use of phytolith characters in the delimitation of Aristida species. Five species of Aristida were included in the study. Various characters like presence or absence of prickle hairs, nature of margins in lobate phytoliths, shank length in relation to the length of lobes etc. proved to be promising characters in the delimitation of the taxa. A taxonomic key to the identification of species is also provided.
\end{abstract}

KEYWORDS: Phytoliths, Poaceae, silica bodies, Aristida

\section{INTRODUCTION}

Phytoliths are silicon depositions in and around the cells of plants. Many plant families are known for their silica deposition. Members of family Poaceae are extensive producers of phytoliths. Phytoliths of Poaceae have been proved to be of great import ance in taxonomy and archeology. Plants deposit silica in almost all the parts including roots, leaves, stem and inflorescence [1] [2] [3]. Eventhough majority of the phytolith production occurs in the epidermal cells, subepidermal silicification is also common.

The aim of the present study was to examine the pattern of phytolith production in five species of Aristida. The data may also be useful in archeological studies as it represents the complete foliar phytolith production in Aristida species.

\section{MATERIALS AND METHODS}

Herbarium specimens collected from Sivaji University Herbarium (SUK), and Calicut University Herbarium (CALI) were utilized for the present study. List of species studied is given in table 1.

Table 1. List of species included in the study

\begin{tabular}{|c|c|c|c|}
\hline Sl. No. & Species & Coll. No. & Subfamily \\
\hline 1. & A. funiculata Trin. \& Rupr. & 1910 & \multirow{5}{*}{ Aristidoideae } \\
\hline 2. & A. hystrix L.f. & 1201 & \\
\hline 3. & A. redacta Stapf & 7053 & \\
\hline 4. & A. setacea Retz. & 11347 & \\
\hline 5. & A. stocksii (Hook.f.) Domin & 1907 & \\
\hline
\end{tabular}

Phytoliths were studied in situ in epidermal peelings as well as in isolation. Isolation procedures and methods of peeling preparation used by Krishnan et al; 2000 [4] were used for the present study.

Phytoliths were photographed using Motic Digital Microscope. Measurements were taken using Motic Image Analysing Software. Various parameters considered were length, width, shank length and shank width. Frequency percentages of each morphotype were calculated by counting about 1000 phytoliths from each species. For measurements as well as frequency percentages, range, average and standard error are provided.

Rules of International Code for Phytolith Nomenclature [5] were applied in naming and classifying the phytoliths.

\section{RESULTS}

Observations of phytoliths in epidermal peelings

1. Aristida funiculata Trin. \& Rupr., Sp. Gram. Stipac.: 159 (1842). 


\section{International Journal of Current Science Research and Review}

ISSN: 2581-8341

\section{Volume 04 Issue 04 April 2021}

DOI: 10.47191/ijcsrr/V4-i4-05, Impact Factor: 5.825

IJCSRR@ 2021

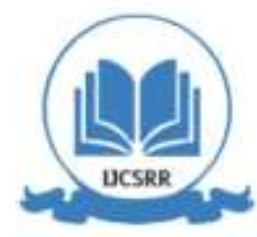

www.ijcsrr.org

Abaxial epidermis: Costal regions with 1-6 rows of bilobate simple types (more than 2 rows occasional), arranged with long axis parallel to the long axis of the leaf, closely packed in rows. Intercostal regions 30-130 $\mu \mathrm{m}$ wide, short cells occasionally silicified, silica bodies narrow elliptic, crescent-shaped, saddle-shaped or irregular-shaped, silicified micro-hairs observed occasionally. (Fig. 1A)
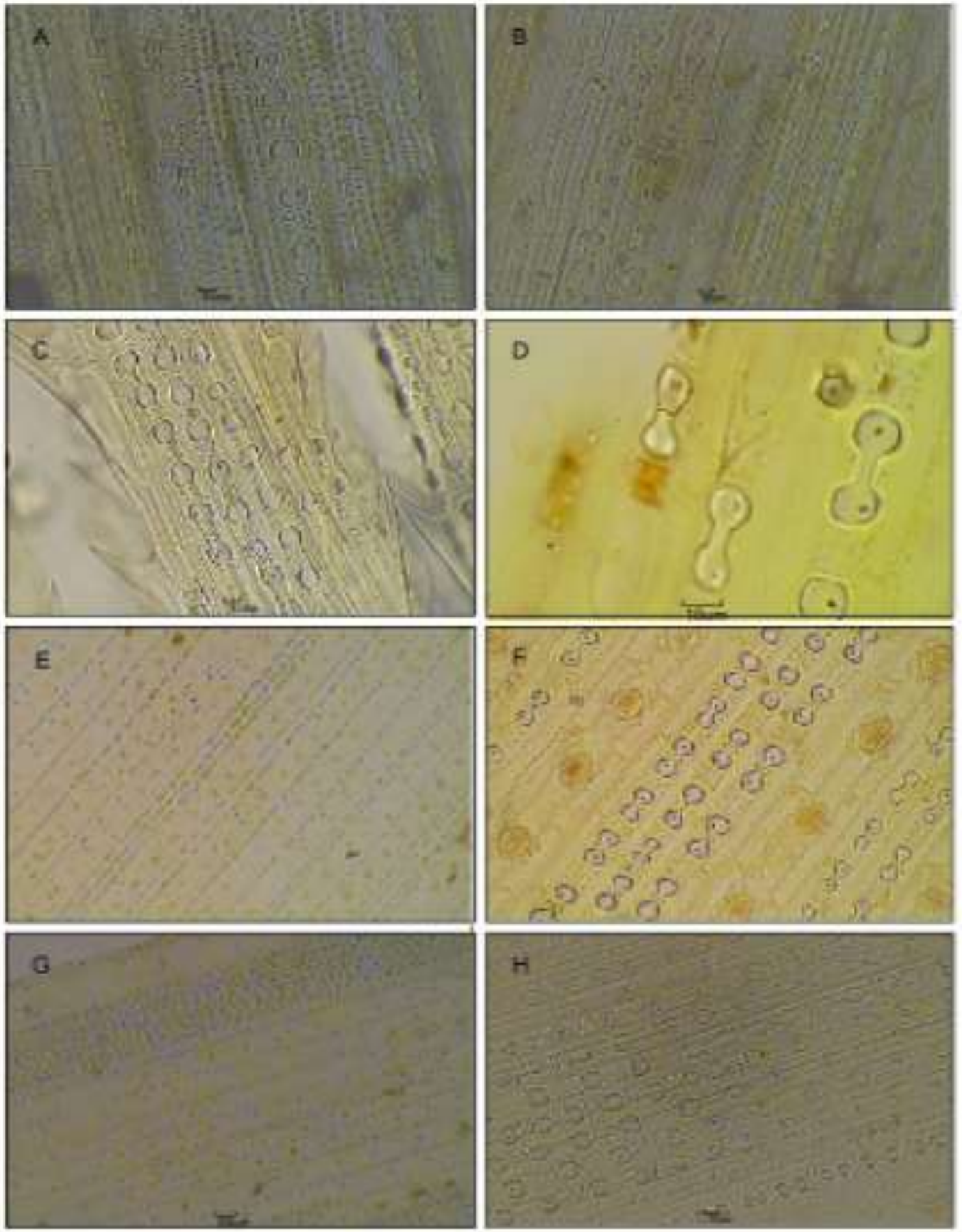

Fig.1. A- Aristida funiculata; B. A. funiculata, ad; C. A. redacta, ab; D. A. setacea, ab; E-F-A. setacea, ad; G- H. A. stocksii, ab.

Ab- Abaxial epidermis; ad- Adaxial epidermis 


\section{International Journal of Current Science Research and Review}

ISSN: 2581-8341

\section{Volume 04 Issue 04 April 2021}

DOI: 10.47191/ijcsrr/V4-i4-05, Impact Factor: 5.825

IJCSRR@ 2021

Adaxial epidermis: Same as abaxial epidermis. (Fig. 1B)
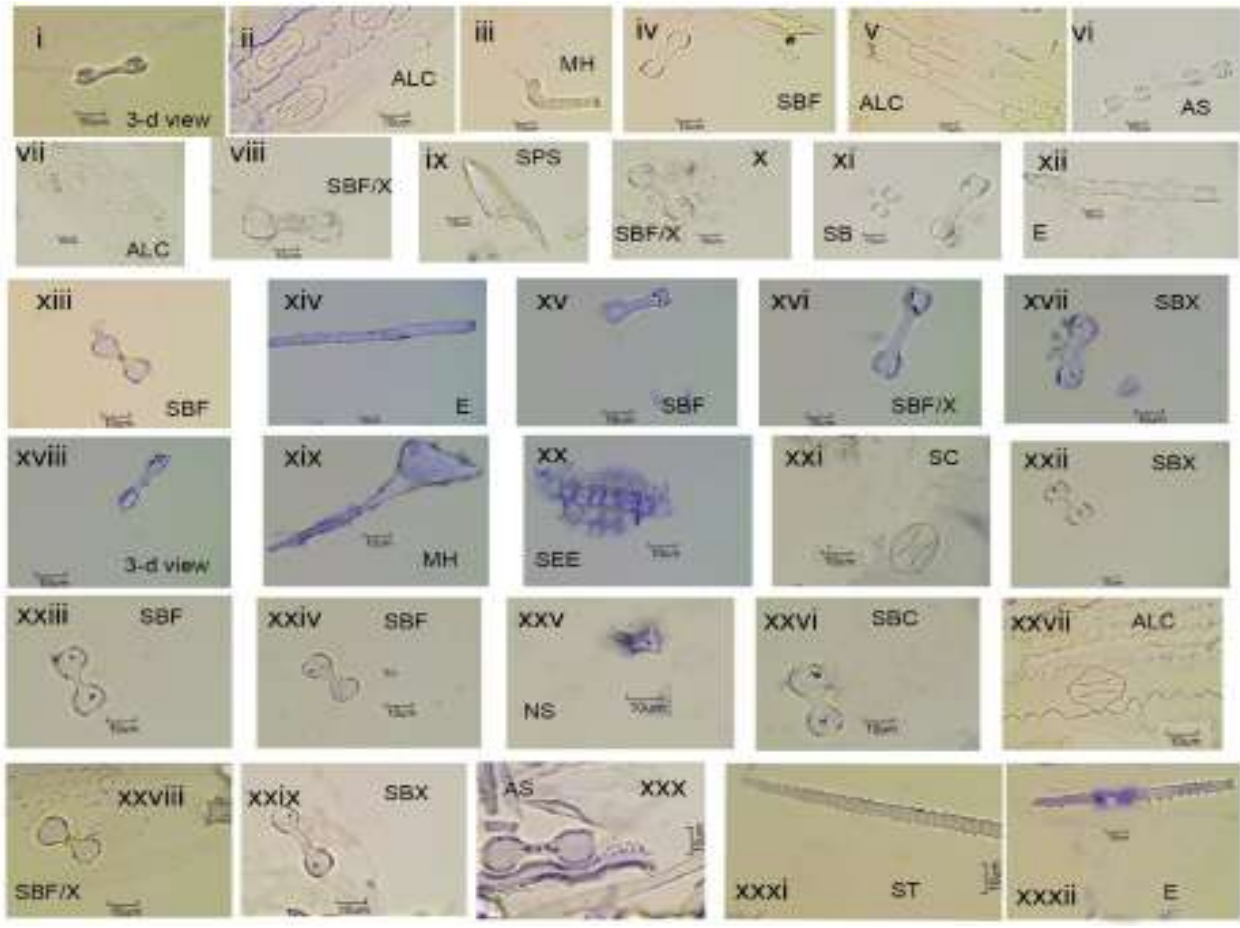

Fig 2: i-v-Aristida funiculata, vi-xi-A. hystrix; xii-xx- A. redacta; xxi-xxvi- A. setacea, xxvi-xxxii- A. stocksii

Voucher specimen: MAHARASHTRA: Kinwat, Potdar 1910 (SUK).

2. Aristida hystrix L.f., Suppl. Pl.: 113 (1782).

Abaxial epidermis: Costal regions composed of 1-8 (more than 2 rows occasional) rows of bilobate simple types, arranged with long axis parallel to the long axis of the leaf, closely packed in rows, prickle-hairs (unciform type) present along the margins of the costal regions. No particular type of margin is found to dominate, rather flattened, concave and flattened/concave margins appear as common types. Intercostal regions 50-75 $\mu \mathrm{m}$ wide, short cells occasionally silicified with short trapezoid phytoliths which appear crescent or saddle-shaped in surface view.

Adaxial epidermis: Prickle-hairs not observed along the margins of the costal regions. All other characters similar to abaxial epidermis.

Voucher specimen: KARNATAKA: Bangalore: South Canara: Vittal, Solly George 3186 (CALI); MAHARASHTRA: Nesari: Kolhapur, Potdar 1201 (SUK).

3. Aristida redacta Stapf, Bull. Misc. Inform. Kew 1892: 85 (1892).

Abaxial epidermis: Costal regions with 1-6 rows (more than 2 rows occasional) of bilobate simple types arranged with long axis parallel to the long axis of the leaf, closely packed in rows, interrupted at intervals and along costal margins by prickles, pricklehairs usually with pointed tip much longer than the swollen base, hairs intermediate between prickle-hairs and macro-hairs also noted. Intercostal regions 20-120 $\mu \mathrm{m}$ wide, short cells devoid of silica bodies, prickle-hairs same as above present at intervals. (Fig. 1.C)

Adaxial epidermis: Prickle-hairs absent, intercostal short cells rarely silicified, silica bodies crescent-shaped or saddle-shaped. All other characters similar to abaxial epidermis.

Voucher specimen: MAHARASHTRA: Amravati: Nandgaon, Yadav 7053 (SUK).

4. Aristida setacea Retz., Observ. Bot. 4: 22 (1786).

Abaxial epidermis: Costal regions with 1-7 rows of bilobate simple types (more than 2 rows occasional) arranged with long axis parallel to the long axis of the leaf, closely packed in rows, prickle-hairs (unciform type) present in between the silica bodies and 


\section{International Journal of Current Science Research and Review}

ISSN: 2581-8341

\section{Volume 04 Issue 04 April 2021}

DOI: 10.47191/ijcsrr/V4-i4-05, Impact Factor: 5.825

IJCSRR@ 2021

www.ijcsrr.org

along the margins in the costal regions. Intercostal regions 55-90 $\mu \mathrm{m}$ wide, short cells devoid of silica, prickle-hairs present at intervals. (Fig1. D)

Adaxial epidermis: Prickle-hairs absent, short cells rarely silicified, silica bodies elliptic or crescent-shaped. All other characters similar to abaxial epidermis. (Fig.1 E\&F)

Voucher specimen: KERALA: Kottayam: Vagamon, Mohanan 11347 (CALI).

5. Aristida stocksii (Hook.f.) Domin, Biblioth. Bot. 20: 338 (1915).

Abaxial epidermis: Costal regions with 1-6 rows (more than 2 rows occasional) of bilobate simple types arranged with long axis parallel to the long axis of the leaf, closely packed in rows, interrupted at intervals and along costal margins by prickle-hairs (unciform type). Intercostal regions 55-85 $\mu \mathrm{m}$ wide, short cells rarely silicified, silica bodies elliptic or crescent-shaped, silicified micro-hairs and macro-hairs observed occasionally. (Fig. 1. G\&H)

Adaxial epidermis: Prickle-hairs absent. All other characters are similar to abaxial epidermis.

Voucher specimen: MAHARASHTRA: Osmanabad: Deobag, Potdar 1907 (SUK).

Isolation studies

Present study could reveal about 9 morphotypes of phytoliths in Aristida species. Morphotype and its abbreviation are shown in table 2 .

Table 2. Major classes of phytoliths and their abbreviation

\begin{tabular}{|c|l|l|}
\hline Sl. No. & ICPN Name & Abbreviation used \\
\hline I. & Articulated forms & \\
\hline 1. & Articulated Epidermal polygonal cells & AEP \\
\hline 2. & Articulated short cells & AS \\
\hline 3. & Subepidermal elements & SEE \\
\hline II. & Isolated forms & E \\
\hline 4. & Elongate & LH \\
\hline 5. & Macro-hairs & MH \\
\hline 6. & Micro-hairs & SPS \\
\hline 7. & Acicular or unciform hair cell & SB \\
\hline 8. & Bilobate simple & NS \\
\hline 9. & Narrow short cells & \\
\hline
\end{tabular}

Frequency percentage of different morphotypes observed in each species is shown in table 3 . For each morphotype, abbreviation shown in the above table is used. Bilobate simple type (SB) followed by $\mathrm{C}, \mathrm{F}$ or $\mathrm{X}$ represent the nature of margins. i.e. concave, flattened or convex respectively. Photographs of isolated phytoliths are provided in Figure 2. Measurements of simple bilobates of each species is shown in Table 4.

Table 3: Frequency percentage of the major classes of phytoliths ( \pm S.E.)

\begin{tabular}{|l|l|l|l|l|l|}
\hline & A. funiculata & A. hystrix & A. redacta & A. setacea & A. stocksii \\
\hline ALC & $40.6 \pm 1.6$ & $25.5 \pm 1.6$ & $5.4 \pm 0.6$ & $13.6 \pm 1.4$ & $23.1 \pm 1$ \\
\hline AS & $7.1 \pm 0.6$ & $4.8 \pm 0.6$ & - & $1.5 \pm 0.5$ & $4.6 \pm 0.8$ \\
\hline SC & - & $2.1 \pm 0.3$ & $0.4 \pm 0.2$ & - & $2.7 \pm 0.3$ \\
\hline
\end{tabular}




\section{International Journal of Current Science Research and Review}

ISSN: 2581-8341

Volume 04 Issue 04 April 2021

DOI: 10.47191/ijcsrr/V4-i4-05, Impact Factor: 5.825

IJCSRR@ 2021

Www.ijesrr.org

\begin{tabular}{|l|l|l|l|l|l|}
\hline SEE & $1.1 \pm 0.4$ & - & - & - & $0.3 \pm 0.2$ \\
\hline ST & $4 \pm 0.7$ & - & - & - & $0.2 \pm 0.1$ \\
\hline E & - & $0.6 \pm 0.2$ & $11.2 \pm 0.6$ & - & $3.2 \pm 0.4$ \\
\hline LH & $3.7 \pm 0.8$ & - & $8.5 \pm 0.3$ & - & - \\
\hline MH & $0.7 \pm 0.3$ & - & - & - & - \\
\hline SPS & $6.9 \pm 0.5$ & $12.9 \pm 0.7$ & $5.3 \pm 0.4$ & $5.4 \pm 0.7$ & $11.7 \pm 1$ \\
\hline NS & $6.3 \pm 0.7$ & $1.5 \pm 0.5$ & $1.1 \pm 0.3$ & $0.5 \pm 0.2$ & $0.7 \pm 0.3$ \\
\hline SBC & $3 \pm 0.3$ & $17.8 \pm 0.8$ & $20.7 \pm 0.7$ & $10.1 \pm 0.6$ & $12.1 \pm 0.5$ \\
\hline SBF & $24.5 \pm 1.8$ & $21 \pm 1.2$ & $21.7 \pm 0.5$ & $58.4 \pm 1.1$ & $22.9 \pm 0.6$ \\
\hline SBX & $0.5 \pm 0.2$ & $0.5 \pm 0.2$ & $8.7 \pm 0.5$ & $2 \pm 0.2$ & $6.1 \pm 0.6$ \\
\hline SBF/C & $4.1 \pm 0.3$ & $10.2 \pm 0.4$ & $14.8 \pm 0.7$ & $6.1 \pm 0.5$ & $3.3 \pm 1$ \\
\hline SBF/X & $2.4 \pm 0.5$ & $1.3 \pm 0.4$ & $1.7 \pm 0.2$ & $2.4 \pm 0.3$ & $7.4 \pm 0.7$ \\
\hline SBX/C & - & $1.8 \pm 0.2$ & $0.5 \pm 0.2$ & - & $1.7 \pm 0.3$ \\
\hline $\begin{array}{l}\text { SB } \\
\text { (Total) }\end{array}$ & $34.5 \pm 1.8$ & $52.6 \pm 1.7$ & $68.1 \pm 0.7$ & $79 \pm 1.4$ & $53.5 \pm 1$ \\
\hline
\end{tabular}

Table 4: Measurements of lobate phytoliths (L- length, W-width, SL- shank length, SW- shank width).

\begin{tabular}{|c|c|c|c|c|c|c|c|c|}
\hline Shape & Dimension & & A. funiculata & A. hystrix & A. redacta & A. setacea & A. stocksii & A. funiculata \\
\hline \multirow{8}{*}{ SB } & \multirow{2}{*}{$\mathrm{L}$} & Avge $\pm S E$ & $20.6 \pm 1$ & $18.5 \pm 0.9$ & $24.4 \pm 1.4$ & $23.4 \pm 2$ & $26 \pm 1.8$ & $24.5 \pm 1.2$ \\
\hline & & Range & $9.3-34.9$ & $16-36.7$ & $15.2-42.4$ & $9.1-41.2$ & $9.4-48$ & $14.5-43.6$ \\
\hline & \multirow{2}{*}{$\mathrm{W}$} & Avge $\pm S E$ & $7.7 \pm 0.3$ & $4.3 \pm 0.2$ & $7.8 \pm 0.3$ & $6.6 \pm 0.2$ & $9.2 \pm 0.4$ & $7.7 \pm 0.2$ \\
\hline & & Range & $4.9-11$ & $4.3-10.2$ & $5.3-12$ & $4.7-9.4$ & $5.7-12.8$ & $4.9-10.2$ \\
\hline & \multirow{2}{*}{ SL } & Avge $\pm S E$ & $5.5 \pm 0.4$ & $5.9 \pm 0.6$ & $6.4 \pm 0.6$ & $7.8 \pm 0.8$ & $6.4 \pm 0.8$ & $7.5 \pm 0.7$ \\
\hline & & Range & $2.1-12$ & $2.2-16.3$ & $2.6-14.7$ & $2.8-16.1$ & $2-15$ & $1.8-19$ \\
\hline & \multirow{2}{*}{ SW } & Avge $\pm S E$ & $3.9 \pm 0.2$ & $1.2 \pm 0.1$ & $2.3 \pm 0.2$ & $2.4 \pm 0.2$ & $2.8 \pm 0.2$ & $3.2 \pm 0.1$ \\
\hline & & Range & $2.2-6.5$ & $1.2-5.1$ & $0.5-4.1$ & $1.3-3.8$ & $1.4-5.9$ & $2.1-4.6$ \\
\hline
\end{tabular}

\section{DISCUSSION}

Taxonomic potential of phytoliths in delimiting the taxa of the family Poaceae have been proved in many studies [4] [6] [7] [8]. The present study aimed at revealing the variation of phytolith characters among 5 species of Aristida to be used in the taxonomic identification of the taxa. The different types of phytolith morphotypes, frequency percentages and pattern of arrangement of phytoliths in the epidermis were observed. Measurement of simple bilobates were taken to determine the potential of size parameters of phytoliths in delimitation of the taxa.

Aristida was found to be an extensive phytolith producer with short cell silica bodies arranged in a tightly packed manner along the costal regions. The genus is characterized by the production of large sized bilobate forms with long or very long shanks according to the size based classification provided in our previous paper [7]. Gallego \& Distel (2004) [8] reported similar observations in A. subulata. Aristida being a species growing in sub arid regions, presence of long shanks and large sized phytoliths can be attributed to grasses growing in semi arid regions. However this can be generalized only through an extensive study of grasses including 


\section{International Journal of Current Science Research and Review}

ISSN: 2581-8341

Volume 04 Issue 04 April 2021

DOI: 10.47191/ijcsrr/V4-i4-05, Impact Factor: 5.825

IJCSRR@ 2021

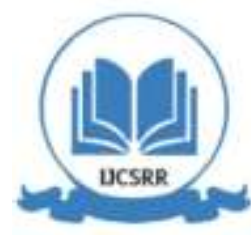

www.ijcsrr.org

numerous species. Three dimensional view of simple bilobates correspond to Chloridoid-type. Also in general the intercostal width is less than $60 \mu \mathrm{m}$. Papilla which is common among the epidermal cells of several grass species is observed to be completely absent in Aristida. Similarly the occurrence of silicified microhairs were also very rare. All other types of lobate phytoliths like complex bilobates and polylobates were lacking. Intercostal short cells are sometimes observed. Their shape ranges from oblong, narrow saddle etc. in surface view, but appear to be horned towers in three dimensional view.

The present study could prepare an identification key to the taxa based on phytolith characters studied. Presence or absence of prickle hairs, nature of predominant margins in the case of simple bilobates, ratio of shank length to the length of the lobes etc. were found to be very useful for the delimitation of species. The shape of outer margins has been reported as a stable character by many earlier workers [9] [10][11].

\section{Key to the species}

1. Prickle-hairs present on either side of the costal regions in the abaxial epidermis..................2

1. Prickle-hairs absent on either side of the costal regions in the abaxial epidermis ......................4

2. Flattened margins common, observed in more than $70 \%$ of the bilobate simple types .................... Aristida setacea

2. Flattened margins never greater than $50 \%$ among bilobate simple types.............................. 3

3. Hairs intermediate between prickles and macro-hairs present...................................... Aristida redacta

3. Hairs intermediate between prickles and macro-hairs absent......................................Aristida stocksii

4. Shank length of bilobate simple types often greater than the length of the lobes ......................Aristida funiculata

4. Shank length of bilobate simple types often almost equal to or less than the length of lobes .............Aristida hystrix

\section{REFERENCES}

1. Geis, J.W. 1978. Biogenic Opal in Three Species of Gramineae. Annals of Botany 42: 1119-1129.

2. Sangster, A.G. and Hodson, M.J. 1992. Silica deposition in subterranean organs. In: Jr. G. Rapp. Phytolith SystematicsEmerging issues 1: 239-251.

3. Alice Novello, Doris Barboni. 2015. Grass inflorescence phytoliths of useful species and wild cereals from sub-Saharan Africa. Journal of Archaeological Science Vol.59: 10-22.

4. Krishnan, S., Samson, N.P., Ravichandran, P., Narasimhan, D. and Dayanandan, P. 2000. Phytoliths of Indian grasses and their potential use in identification. Botanical Journal of Linnean Society 132: 241-252.

5. Madella, M., Alexandre, A. and Ball, T. 2005. International code for phytolith nomenclature 1.0. Annals of Botany 96: 253-260.

6. Metcalfe, C.R. 1960. Anatomy of the Monocotyledons. 1. Gramineae. Claredon Press, Oxford: 731pp.

7. Jattisha PI and Sabu M, 2012. Phytoliths as a tool for the identification of some Chloridoideae Grasses in Kerala, International Scholarly Research Network. 1: 1-9.

8. Jattisha, P. I., and Sabu, M. (2015). Foliar phytoliths as an aid to the identification of Paniceae (Panicoideae: Poaceae) grasses in South India. Webbia- Journal of Plant Taxonomy and Geography. 70, 115-131.

9. Fahmy, A.G. 2008. Diversity of lobate phytoliths in grass leaves from the Sahel region, West Tropical Africa: Tribe Paniceae. Plant Systematics and Evolution 270: 1-23.

10. Lu, H.Y. and Liu, K.B. 2003. Morphological variations of lobate phytoliths from grasses in China and South eastern USA. Diversity and Distributions 9: 73-87.

11. Fahmy, A.G. 2008. Diversity of lobate phytoliths in grass leaves from the Sahel region, West Tropical Africa: Tribe Paniceae. Plant Systematics and Evolution 270: 1-23.

Cite this Article: PI. Jattisha, M. Sabu (2021). Characterisation of Phytolith Production and Their Taxonomic Use among Five Species of Aristida. International Journal of Current Science Research and Review, 4(4), 273-278 